\title{
Temperatures in the Life Zones of the Tyrolean Alps
}

\author{
By \\ Walter Larcher and Johanna Wagner \\ (Vorgelegt in der Sitzung der math.-nat. Klasse am 16. Dezember 2010 durch \\ das w. M. Walter Larcher)
}

\begin{abstract}
The bioclimatic temperatures that mountain plants experience are very different from the macroclimatic temperatures and vary according to the exposition, relief, and growth form. This is shown in the example of boundary layer temperatures recorded in the Tyrolean Alps between the timberline and the nival zone over several years. Microsite temperatures were compared to the air temperatures provided by meteorological stations of the official weather service nearby.

In winter plant temperatures below the snow are largely uncoupled from the free air temperatures. During the growing season, across all zones, plant temperatures diverge to differing degrees from free air temperatures depending on the growth form of plants and the canopy structure. In Vaccinietum communities and in closed grassland, average temperature differences between the free air and plant canopy were $0.5 \mathrm{~K}$ in July and August. Prostrate mats of the Loiseleuria heath, rosette and cushion plants, however, heat up much more than erect plants during sunny periods, and mean plant temperatures were about $2-3 \mathrm{~K}$ warmer than the free air temperatures. As a result, the adiabatic lapserate for bioclimatic temperatures of the life zones in the Alps does not parallel the adiabatic lapse rate of free air temperatures.
\end{abstract}

\section{Introduction}

The elevational zonation of the vegetation in high mountains reflects the different growth limits of plant species. The decrease of diversity and density of species mirror the adverse life conditions $[17,33]$. The 
high mountain climate is defined by a small-scale, terrain-dependent and short-term changeability $[1,42]$. Sunny slopes and windy ridges are fairly dry and show rather little snow in winter whereas sheltered depressions are relatively wet in summer and permanently covered with snow during winter. Above the timberline, the duration of snow cover not only depends on the altitude but also on topography. With incomplete snow cover, characteristic patterns of snow patches and snowmelt areas develop for a given terrain. In these patches, which can be covered by winter snow as late as mid June and August, the growing season is very short and thus unfavourable for growth and development of high mountain plants.

The bioclimate, which is the microclimate from the upper surface of the vegetation down to the deepest roots in the soil is more balanced, warmer and wetter than the surrounding air [31]. Among the different climatic factors, temperature is of crucial importance to the life processes of plants. The thermal climate that mountain plants experience is very different from free-air temperatures. The boundary layer temperatures in micro-habitats demonstrate that weather services data are unable or not relevant [37]. In the night, plant temperatures are similar to the free-air temperatures or, due to radiation cooling, are even lower. During the daytime hours, plants can considerably heat up above the air temperature on clear days with low wind, whereas in periods with clouds, wind and precipitation plant temperatures approximate to the air temperatures $[4,24]$.

Plant architecture and thus the canopy structure additionally affects the thermal bioclimate. Generally, prostrate growing plants as prostrate dwarf shrubs, rosettes and cushions decouple their climate stronger from the ambient than erect plant forms in that they accumulate more heat during daytime at high irradiation, but may also lose more heat by thermal re-radiation at clear sky during the night [17].

In the last 50 years of mountain research in the Tyrolean Alps comprehensive microclimatic and ecological studies have been carried out. In this contribution, representative examples of plant temperatures in diverse habitats between timberline (1950 $\mathrm{m}$ a.s.1.) and glacier regions (subnival and nival zone up to $3450 \mathrm{~m}$ a.s.l.) are presented and compared to the air temperatures recorded by the nearest meteorological stations of the official weather service. Study sites were in a treeline ecotone $[2,41,46]$, in dwarf-shrub communities of the lower alpine zone [4, 23], in closed alpine grassland (e.g. $[6,40])$, in open alpine vegetation and in the alpine-nival ecotone (e.g. $[22,30,35])$, and in a nival area with scant patchy vegetation $[32,44]$. 


\section{Air Temperatures Beyond of the Timberline}

Air temperatures steadily decrease with increasing elevation. In the Alps, the temperatures of the free atmosphere are reduced, according to the adiabatic lapse rate, which amounts to $0.55-0.62^{\circ} \mathrm{C}$ (annual mean) and $0.60-0.65^{\circ} \mathrm{C}$ (in summer) per $100 \mathrm{~m}$ from the bottom of the valley to the high mountain regions [11]. In the Tyrolean Central Alps (period 1995-2009), the annual mean adiabatic lapse rate amounts to $0.59^{\circ} \mathrm{C} /$ $100 \mathrm{~m}$ between the timberline $(1950 \mathrm{~m}$ a.s.l.) and the glacier foreland ( $2850 \mathrm{~m}$ a.s.l.), and to $0.46{ }^{\circ} \mathrm{C} / 100 \mathrm{~m}$ between the upper alpine zone (2247 $\mathrm{m}$ a.s.l.) and the glacier foreland.

In the Central Alps, the annual mean air temperatures were $3.0^{\circ} \mathrm{C}$ at the timberline (Mt Patscherkofel; $1950 \mathrm{~m}$ a.s.l.), $0.5^{\circ} \mathrm{C}$ in the alpine zone (summit of Mt Patscherkofel; $2247 \mathrm{~m}$ a.s.1.), $-2.3^{\circ} \mathrm{C}$ at the glacier foreland (Mittelbergferner, Ötztal Alps; $2850 \mathrm{~m}$ a.s.1.) and $-5.8^{\circ} \mathrm{C}$ in the nival zone (Mt Brunnenkogel, Ötztal Alps; $3440 \mathrm{~m}$ a.s.l.). Mean temperatures during summer were $10.6{ }^{\circ} \mathrm{C}$ in July and $10.7^{\circ} \mathrm{C}$ in August at the timberline, $8.5^{\circ} \mathrm{C}$ in the upper alpine zone in both months, 5.6 and $5.7^{\circ} \mathrm{C}$ in the glacier foreland, and only $1.6^{\circ} \mathrm{C}$ and $1.9^{\circ} \mathrm{C}$ in the nival zone (Tables $1-4$ ). The long-time temperatures in the alpine zone calculated for the climate normal period 1961-1990 on the

Table 1. Air temperatures at $2 \mathrm{~m}$ height at the timberline of Mt Patscherkofel $(1950 \mathrm{~m}$ a.s.l.; $11^{\circ} 27^{\prime} 02^{\prime \prime} \mathrm{E}-47^{\circ} 12^{\prime} 22^{\prime \prime} \mathrm{N}$ ) provided by the Federal Office and Research Centre for Forests (G. WIESER; unpubl. data). (Tm) mean air temperature; (Max abs) absolute maximum; (Min abs) absolute minimum. Frost-free: number of days with $>0{ }^{\circ} \mathrm{C}$

\begin{tabular}{lrlll}
\hline 1995-2009 & Tm & Max abs & Min abs & Day with frost-free \\
\hline January & -3.9 & 14.4 & -20.0 & 8 \\
February & -4.0 & 12.6 & -19.0 & 8 \\
March & -2.3 & 13.9 & -19.6 & 11 \\
April & 1.0 & 17.3 & -16.4 & 15 \\
May & 6.3 & 23.0 & -8.1 & 28 \\
June & 9.4 & 25.1 & -4.5 & 25 \\
July & 10.6 & 25.0 & -2.6 & 29 \\
August & 10.7 & 25.8 & -0.9 & 30 \\
September & 7.1 & 22.9 & -5.2 & 22 \\
October & 4.9 & 21.2 & -11.2 & 23 \\
November & -0.8 & 14.4 & -22.4 & 13 \\
December & -3.5 & 11.4 & -22.9 & 9 \\
\hline Year & $\mathbf{3 . 0}$ & & & 220 \\
Extreme & & $25.8(2003)$ & $-22.9(2001)$ & \\
\hline
\end{tabular}


Table 2. Air temperatures at $2 \mathrm{~m}$ height at the summit of Mt Patscherkofel (2247 $\mathrm{m}$ a.s.l.; $11^{\circ} 27^{\prime} 39^{\prime \prime} \mathrm{E}-47^{\circ} 12^{\prime} 31^{\prime \prime} \mathrm{N}$ ) provided by Central Institute for Meteorology and Geodynamics, Regional Center for the Tyrol and Vorarlberg. (Tm) mean air temperature; (Max abs) absolute maximum; (Min abs) absolute minimum. Frost-free: number of days with $>0{ }^{\circ} \mathrm{C}$

\begin{tabular}{lrclc}
\hline 1995-2009 & Tm & Max abs & Min abs & Day with frost-free \\
\hline January & -6.1 & 9.0 & -21.8 & 1 \\
February & -6.5 & 8.6 & -23.8 & 1 \\
March & -5.0 & 9.7 & -22.5 & 2 \\
April & -1.9 & 11.5 & -18.8 & 6 \\
May & 3.6 & 18.3 & -8.6 & 19 \\
June & 6.9 & 21.5 & -6.9 & 24 \\
July & 8.5 & 20.2 & -2.8 & 29 \\
August & 8.5 & 21.8 & -3.8 & 30 \\
September & 4.8 & 18.8 & -6.4 & 22 \\
October & 2.6 & 15.7 & -12.9 & 18 \\
November & -3.2 & 10.6 & -19.4 & 4 \\
December & -5.7 & 7.3 & -23.4 & 1 \\
\hline Year & $\mathbf{0 . 5}$ & & & 156 \\
Extreme & & $21.8(2003)$ & $-23.8(2005)$ & \\
\hline
\end{tabular}

Table 3. Air temperatures at $2 \mathrm{~m}$ height at the Mittelbergferner (Ötztal Alps $2850 \mathrm{~m}$ a.s.l.; $10^{\circ} 52^{\prime} 58^{\prime \prime} \mathrm{E}-46^{\circ} 55^{\prime} 33^{\prime \prime} \mathrm{N}$ ) provided by Central Institute for Meteorology and Geodynamics, Regional Center for the Tyrol and Vorarlberg. (Tm) mean air temperature; (Max abs) absolute maximum; (Min abs) absolute minimum. Frost-free: number of days with $>0{ }^{\circ} \mathrm{C}$

\begin{tabular}{lrcll}
\hline 1995-2009 & Tm & Max abs & Min abs & Day with frost-free \\
\hline January & -8.7 & 5.8 & -26.0 & 0 \\
February & -9.3 & 6.9 & -29.0 & 0 \\
March & -8.0 & 6.8 & -26.3 & 0 \\
April & -5.0 & 8.0 & -23.4 & 0 \\
May & 0.4 & 13.0 & -14.7 & 8 \\
June & 3.6 & 15.4 & -11.2 & 16 \\
July & 5.6 & 17.6 & -6.6 & 22 \\
August & 5.7 & 17.5 & -6.3 & 25 \\
September & 2.2 & 15.3 & -10.1 & 15 \\
October & 0.1 & 12.6 & -19.4 & 9 \\
November & -5.7 & 9.5 & -21.7 & 1 \\
December & -8.3 & 5.3 & -25.2 & 0 \\
\hline Year & $-\mathbf{2 . 3}$ & & & \\
Extreme & & $17.6(2005)$ & $-29.0(2005)$ & \\
\hline
\end{tabular}


Table 4. Air temperatures at $2 \mathrm{~m}$ height at the summit of Mt Brunnenkogel (Ötztal Alps $3440 \mathrm{~m}$ a.s.l.; $10^{\circ} 51^{\prime} 42^{\prime \prime} \mathrm{E}-46^{\circ} 54^{\prime} 46^{\prime \prime} \mathrm{N}$ ) provided by Central Institute for Meteorology and Geodynamics, Regional Center for the Tyrol and Vorarlberg. (Tm) mean air temperature; (Max abs) absolute maximum; (Min abs) absolute minimum. Frost-free: number of days with $>0{ }^{\circ} \mathrm{C}$

\begin{tabular}{lrlll}
\hline 2003-2009* $^{*}$ & Tm & Max abs & Min abs & Day with frost-free \\
\hline January & -12.5 & 0.0 & -29.1 & 0 \\
February & -13.5 & 1.0 & -30.8 & 0 \\
March & -12.3 & 1.7 & -28.4 & 0 \\
April & -7.7 & 0.9 & -20.0 & 0 \\
May & -3.9 & 8.8 & -18.6 & 2 \\
June & -0.5 & 11.0 & -14.7 & 7 \\
July & 1.9 & 12.3 & -9.0 & 15 \\
August & 1.6 & 12.7 & -10.5 & 13 \\
September & -0.1 & 11.9 & -12.3 & 8 \\
October & -3.3 & 8.7 & -22.2 & 3 \\
November & -8.2 & 3.2 & -24.1 & 0 \\
December & -11.5 & 1.1 & -30.0 & 0 \\
\hline Year & $-\mathbf{5 . 8}$ & & & 48 \\
Extreme & & $12.7(2003)$ & $-30.8(2005)$ & \\
\hline
\end{tabular}

* In operation since 2003

basis of $2 \mathrm{~m}$ air temperature on Mt Patscherkofel amounts to $0.2{ }^{\circ} \mathrm{C}$ for the annual mean, and 8.0 and $8.1^{\circ} \mathrm{C}$ for the summer months July and August.

The number of frost-free days per year declines from 220 days at the timberline to 156 days in the upper alpine zone, to 94 days in the glacier foreland and to 48 days in the nival zone. During midsummer (July to August) freezing temperatures from $-3{ }^{\circ} \mathrm{C}$ in the alpine zone to $-7^{\circ} \mathrm{C}$ in the subnival zone and $-10^{\circ} \mathrm{C}$ in the nival zone can occur. During winter, absolute minima of the air temperature of the free atmosphere ranged from -23 to $-24^{\circ} \mathrm{C}$ in the treeline ecotone and alpine zone, and reached as low as -29 and $-31^{\circ} \mathrm{C}$ in glacier regions. However, most high mountain plants are hardly affected by these low temperatures as they are protected by a layer of snow.

\section{Temperatures in the Alpine Dwarf-shrub Heath}

In the Central Alps the alpine dwarf shrub heath covers the treeline ecotone and the lower alpine zone [14]. Rhododendron ferrugineum grows beyond the timberline (ca. 1900-2000 m a.s.l.) followed by the Rhododendro-Vaccinietum community with Vaccinium myrtillus, 

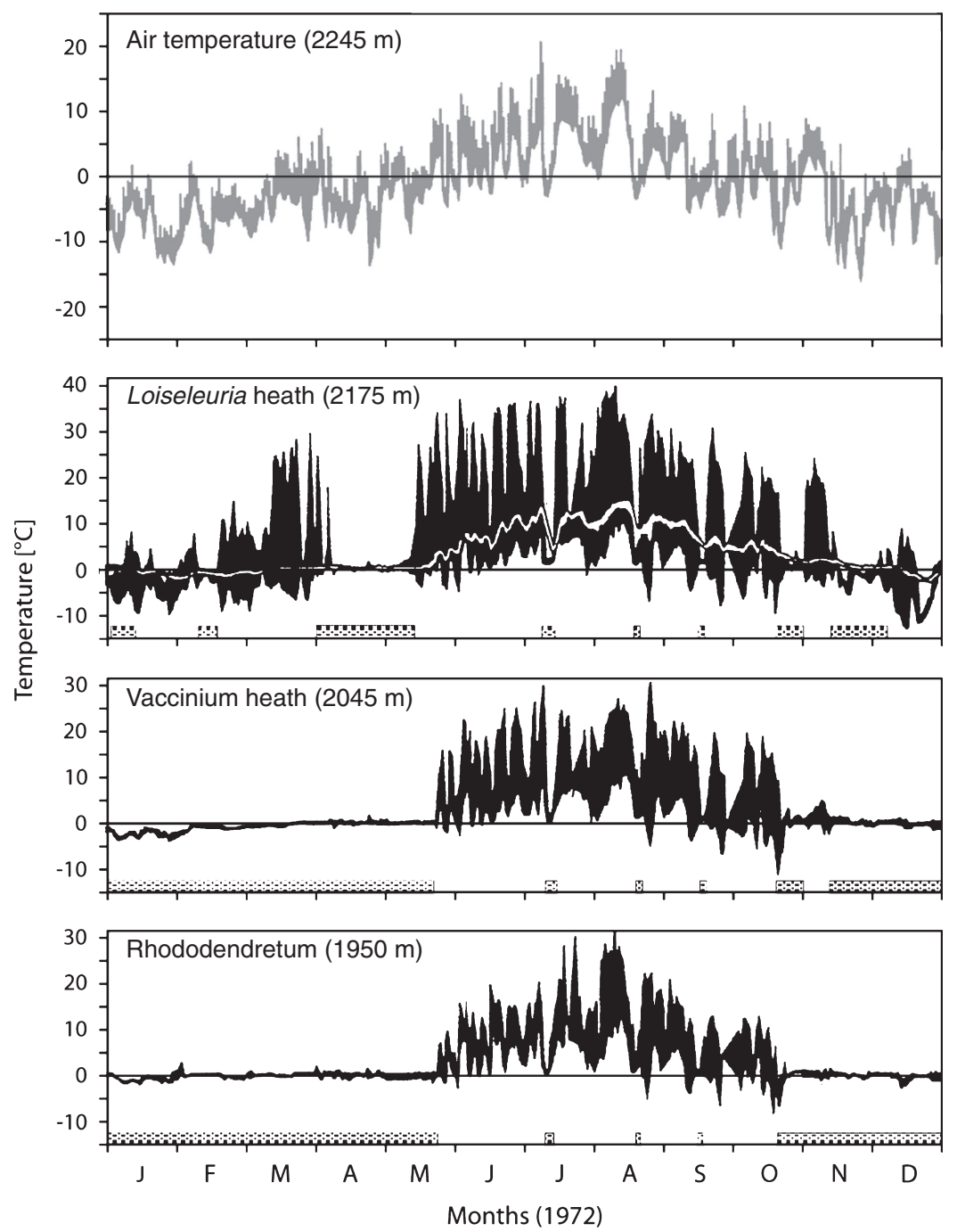

Fig. 1. Annual course of air temperature $(2 \mathrm{~m})$ and canopy temperatures of dwarf shrub heaths measured in three different plant communities at different sites in the Central Alps near Innsbruck (Mt Patscherkofel; 2247 m a.s.1.). Even though 1972 was a cool year, the absolute minimum temperatures were not very low during winter. Black area: daily minimum and maximum temperatures. White strip: soil temperature at $10 \mathrm{~cm}$ depth in Loiseleuria heath. Grey bars: snow cover. Temperatures were recorded with mobile meteorological equipment using platinum thermometers ([4], modified) 
V. uliginosum and Calluna vulgaris. The limit of the dwarf shrub belt is reached at ca. 2200-2400 m a.s.1. Here, prostrate mats of LoiseleurioCetrarietum (Loiseleuria procumbens and lichens) are found. Figure 1 shows annual time courses of canopy temperatures in three different dwarf shrub heaths and air temperatures at $2 \mathrm{~m}$ on Mt Patscherkofel near Innsbruck. In 1972 the annual means of canopy temperatures were $2.8^{\circ} \mathrm{C}$ within the $60 \mathrm{~cm}$ high Rhododendron shrubs, $3.4^{\circ} \mathrm{C}$ in the $1.5 \mathrm{~cm}$ high prostrate mats of Loiseleuria and $2.7^{\circ} \mathrm{C}$ in the $20-26 \mathrm{~cm}$ high Vaccinium heaths.

In winter, Rhododendron shrubs and Vaccinium heaths are usually protected from low temperatures by a snow cover which lasts for 6 months. In early winter, however, lower temperatures can occur due to thin layers of snow. The generally wind-blown Loiseleuria heath is only covered by snow for 4-5 months because of snow drift. Under sunny conditions and in the absence of snow cover above-ground plant parts can warm up considerably at noon. On a clear winter day in 1972, for example, air temperatures of $-5^{\circ} \mathrm{C}$ were measured, while temperatures of $+15^{\circ} \mathrm{C}$ and $+20^{\circ} \mathrm{C}$ occurred in the prostrate mats of Loiseleuria and $+10^{\circ} \mathrm{C}$ and $+13^{\circ} \mathrm{C}$ in low Calluna-shrubs [23].

In summer, the temperatures very seldom dropped below $-3{ }^{\circ} \mathrm{C}$ in the dwarf-shrub heaths. During the climatically potential growing season the average mean temperatures were about $7-8^{\circ} \mathrm{C}$ in Rhododendron shrubs at the treeline [27]. A frequency distribution was calculated for the same habitat (Fig. 2); temperatures of $0-5^{\circ} \mathrm{C}$ occurred most

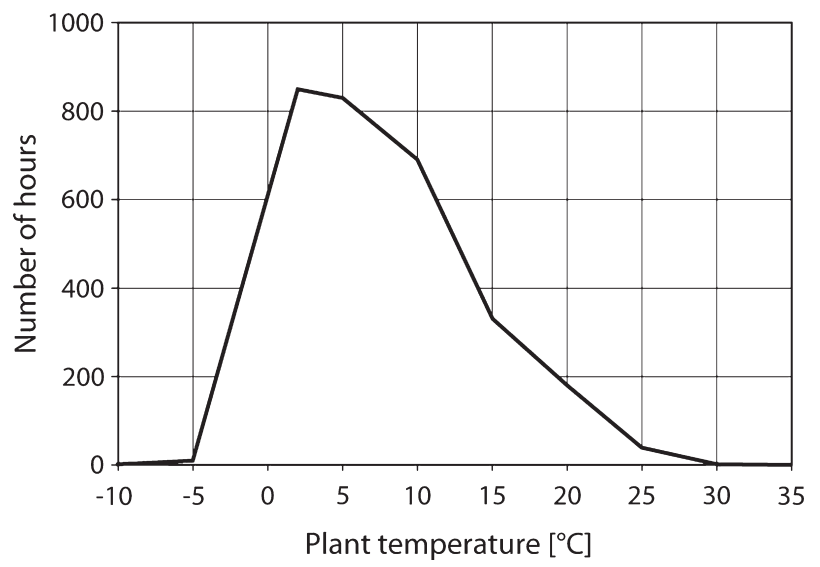

Fig. 2. Frequency distribution of shrub temperatures measured in Rhododendron ferrugineum (at $45 \mathrm{~cm}$ height) at the timberline (1950 m a.s.1.) from May 1 to September 15, 1982. Recorded by platinum thermometers. Data by SIEGWOLF [38] 
frequently (35\% of the hours measured) and temperatures of $5-10{ }^{\circ} \mathrm{C}$ were second most frequent ( $32 \%$ of the hours measured). Frosty temperatures as low as -6 to $-7{ }^{\circ} \mathrm{C}$ occurred with a frequency of $13 \%$ in May and from September to October.

In the low prostrate mats of Loiseleuria mean maximum temperatures of $20-30^{\circ} \mathrm{C}$ were recorded in the summer. Short-term temperatures of $30-32{ }^{\circ} \mathrm{C}$ were repeatedly measured on south exposed slopes, maximum temperatures were as high as $35-38^{\circ} \mathrm{C}$. On summer days with strong incoming radiation absolute maximum leaf temperatures of $40-42{ }^{\circ} \mathrm{C}$ and boundary layer temperatures of up to $50^{\circ} \mathrm{C}$ occurred. When skies are clear, soil is dry and there is little wind the patches of bare humic soil in the vegetation gaps can even reach surface temperatures as high as $50-55^{\circ} \mathrm{C}$ [20].

\section{Temperatures in the Alpine Grassland}

Closed vegetation with plant growth forms characteristic of alpine grasslands cover the broad transect from the timberline to about $2500 \mathrm{~m}$ a.s.1. In the Central Alps, Sieversio-Nardetum strictae and

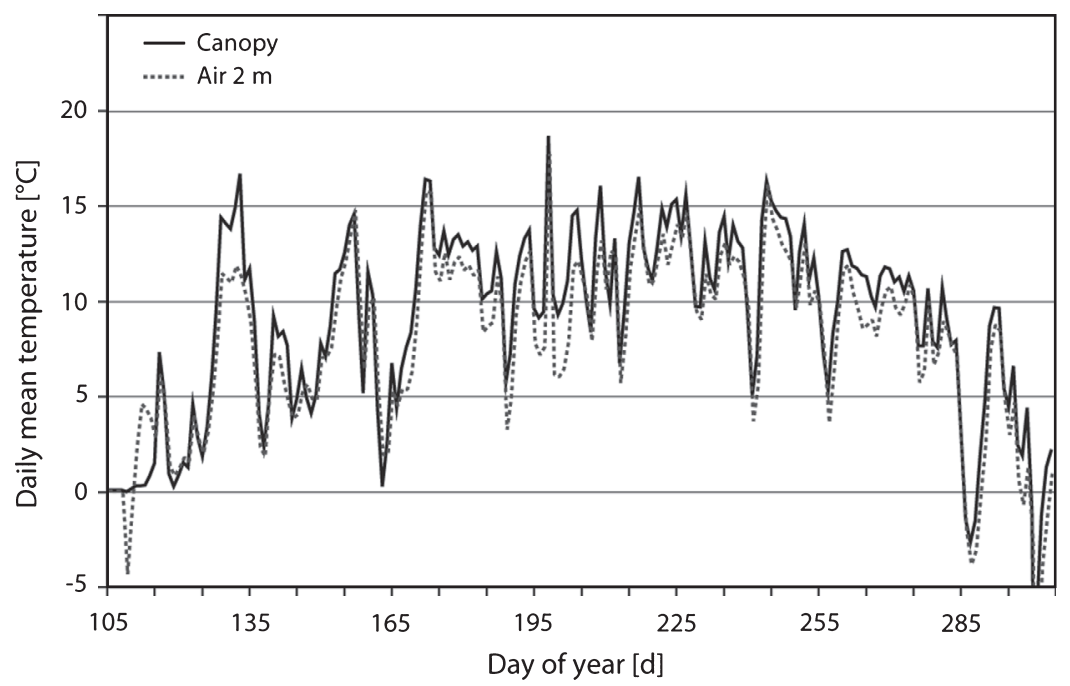

Fig. 3. Variation in daily mean canopy and free atmosphere temperatures during the growing season on a S-facing slope at $2000 \mathrm{~m}$ a.s.l. in the Passeier valley (Stubai Alps; $\left.11^{\circ} 15^{\prime} 50^{\prime \prime} \mathrm{E}-46^{\circ} 49^{\prime} 56^{\prime \prime} \mathrm{N}\right)$. Solid line: canopy temperature; thin line: air temperature at $2 \mathrm{~m}$ height. Temperatures were recorded using small data loggers with a NTC-pearl sensor. Data by E. TASSER [40] 
Caricetum curvulae (Curvuletum) form the upper alpine grassland plant communities while in the Calcareous Alps Seslerio-Caricetum sempervirentis (Seslerio-Semperviretum) and Festuca-communities are found [13]. These alpine grasslands occur on S- or SW-facing slopes which benefit from the steep radiation angle and are therefore warmer and drier than the shady $\mathrm{N}$-facing slopes or depressions.

On a sunny slope at $2000 \mathrm{~m}$ a.s.l. in the Stubai Alps variations in daily mean temperatures were measured in a community of Caricetumsempervirentis and Nardetum strictae during the climatically potential growing season from mid April until the end of October (Fig. 3). During the investigated growing season the daily mean air temperatures were $9.3 \pm 4.5^{\circ} \mathrm{C}$, and $8.3 \pm 4.1^{\circ} \mathrm{C}$ within the canopy [40]. The highest daily mean temperatures were $18.6^{\circ} \mathrm{C}$ (canopy) and $17.7^{\circ} \mathrm{C}$ (at $2 \mathrm{~m}$ ); the lowest were $-2.6{ }^{\circ} \mathrm{C}$ (canopy) and $-3.9^{\circ} \mathrm{C}$ (at $2 \mathrm{~m}$ ).

In the canopy, the $+5^{\circ} \mathrm{C}$ daily mean temperature threshold was passed in the first week of May (day of year 127) and stayed above this level until October 1997 (day of year 296). This base temperature of $5 \pm 2{ }^{\circ} \mathrm{C}$ is enough for sedges and grasses to maintain continuous growth [25]. In May, heading and anthesis (threshold $10-12{ }^{\circ} \mathrm{C}$ ) occur. Between June (day of year 170) and September (day of year 254) fluctuating daily mean temperatures of between $10-15^{\circ} \mathrm{C}$ were recorded. Metabolism, storage and reproduction peak during these 12 weeks $[36,43]$.

At the same altitude considerable differences in canopy temperatures between SW-facing and NE-facing slopes were observed. Two temperature loggers were positioned on the summit of Mt Patscherkofel (southern slope: $2200 \mathrm{~m}$ a.s.1., $25^{\circ}$ inclination; northern slope: $2230 \mathrm{~m}$ a.s.l., $35^{\circ}$ inclination) to record the temperatures in the Curvuletum (Table 5).

Table 5. Canopy temperatures and dates of different sites of upper alpine grassland during the snow free-period during the climatically normal year in 2000

\begin{tabular}{llc}
\hline Characteristics & $\begin{array}{l}\text { North-east site } \\
2230 \mathrm{~m} \text { a.s.l. }\end{array}$ & $\begin{array}{c}\text { Southwest site } \\
2200 \mathrm{~m} \text { a.s.l. }\end{array}$ \\
\hline $\begin{array}{l}\text { Mean plant temperatures } \\
\text { during the snow-free period }\end{array}$ & $6.4^{\circ} \mathrm{C}$ & $8.5^{\circ} \mathrm{C}$ \\
Most frequent temperature range & $0-5^{\circ} \mathrm{C}$ & $5-10^{\circ} \mathrm{C}$ \\
Absolute maximum & $29.4^{\circ} \mathrm{C}$ & $34.3^{\circ} \mathrm{C}$ \\
Absolute minimum & $-3.5^{\circ} \mathrm{C}$ & $-2.7^{\circ} \mathrm{C}$ \\
Length of the & $145 \mathrm{~d}$ & $154 \mathrm{~d}$ \\
$\quad$ snow-free period & $52 \mathrm{~d}$ & $32 \mathrm{~d}$ \\
Days with $\leq 0^{\circ} \mathrm{C}$ & $93 \mathrm{~d}$ & $112 \mathrm{~d}$ \\
Days with $>00^{\circ} \mathrm{C}$ & & \\
\hline
\end{tabular}


The mean boundary layer temperatures on the sunnier SW-facing slope were higher by $2 \mathrm{~K}$ than on the cooler NE-facing slope throughout the whole growing season.

Throughout the whole measuring period temperatures ranging from 5 to $10^{\circ} \mathrm{C}$ were most common on the SW-facing slope. On the NEfacing slope temperatures between 0 and $5{ }^{\circ} \mathrm{C}$ were most common. In addition, for the SW-facing slope, the frequency of the daylight and night hours was calculated separately. During the night, temperatures between 0 and $5^{\circ} \mathrm{C}$ as well as 5 and $10^{\circ} \mathrm{C}$ were most frequent. During daylight hours the range of the frequency distribution was much broader, namely $0-20^{\circ} \mathrm{C}$. In the snow free period (May until June) there were 32 days of night frost (absolute minimum $-2.7^{\circ} \mathrm{C}$ ) on the $\mathrm{SW}$-facing slope and 52 days of frost (absolute minimum $-3.5^{\circ} \mathrm{C}$ ) on the NE-facing slope. The monthly means of the daily maximum were $17^{\circ} \mathrm{C}$ (July) and $24^{\circ} \mathrm{C}$ (August) on the SW-slope and $15^{\circ} \mathrm{C}$ (July) and $18^{\circ} \mathrm{C}$ (August) on the NE-slope.

CERNUSCA and SEEBER [7] investigated the vertical profiles of temperature, of a Curvuletum in the Hohe Tauern at an altitude of

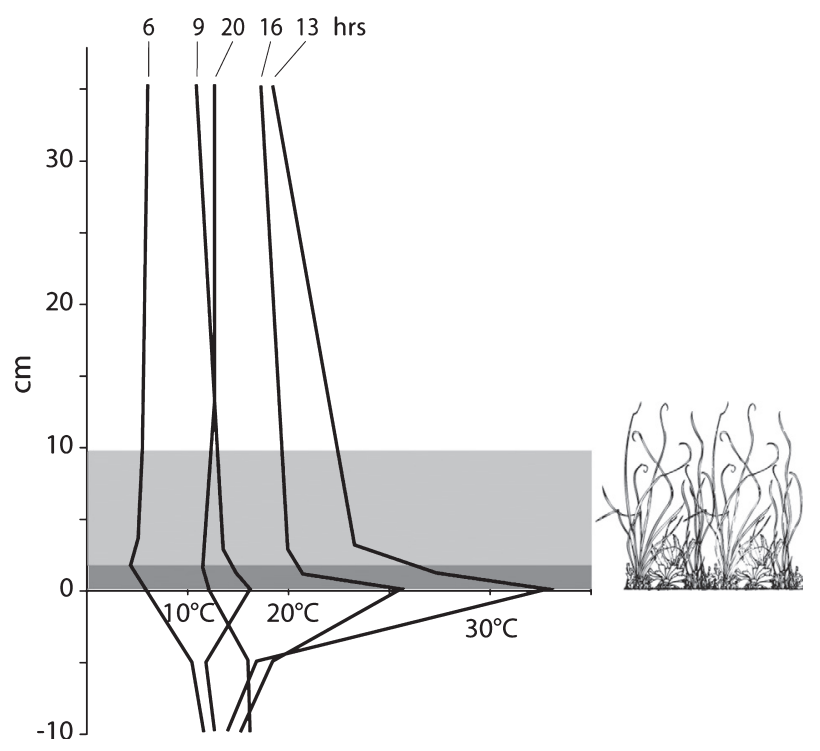

Fig. 4. Vertical distribution of air and soil temperatures $(\mathrm{T})$ measured on a clear day in the Curvuletum at $2300 \mathrm{~m}$ a.s.l. Canopy structure: shaded light area: graminoids growth form (mostly Carex curvula), dark area: layer of rosettes (e.g. Primula minima). Temperatures were recorded with mobile meteorological equipment using platinum thermometers [5] 
$2300-2400 \mathrm{~m}$ a.s.l. The average height of the canopy is $6-12 \mathrm{~cm}$ and shows a two layer structure: the top layer is mostly made up of Carex curvula and other grasses, whereas the underlying layer consists of prostrate herbaceous vascular plants, mosses and lichens. The top layer is more often exposed to wind with extensive heat transfer and little overheating under conditions of intensive solar radiation. The bottom layer $\left(0^{\circ} \mathrm{C}\right.$ to $\left.2 \mathrm{~cm}\right)$ is not only wind protected but also warmer (ca. $10-15 \mathrm{~K})$.

On a bright summer day in August the daily fluctuations of temperatures were $9.5 \mathrm{~K}$ at $2 \mathrm{~m}, 19 \mathrm{~K}$ at the average canopy height of the Curvuletum and $36 \mathrm{~K}$ at the boundary layer. During the night canopy temperatures dropped considerably due to thermal re-radiation. In the morning, canopy temperatures were below the temperatures at $2 \mathrm{~m}$. With increasing incoming radiation the canopy heated up. A clear overheating of the canopy can also be detected in the daily mean temperatures. Thus, on a clear sunny day, daily means of boundary layer temperatures were $5 \mathrm{~K}$ higher than the daily mean temperature at $2 \mathrm{~m}$. Temperatures at $3 \mathrm{~cm}$ were only higher than the daily mean temperature at $2 \mathrm{~m}$ by $1 \mathrm{~K}$ (Fig. 4). On cloudy days the heating effect is only half as big.

\section{Temperatures in Open Alpine Vegetation}

Beyond the closed alpine grassland the sparse vegetation of the upper alpine life zone begins. The prostrate plant life forms like dwarf shrubs, short graminoids, rosettes and cushion plants inhabit the micro-habitats. Figure 5 shows examples of the annual course of boundary layer temperatures at two contrasting sites.

In winter, prostrate plants growing at microsites sheltered from the wind are mostly covered with snow. Until the end of May these plants experience temperatures between 0 and $-3{ }^{\circ} \mathrm{C}$. Pioneer plants and cushion plants growing at sites exposed to the wind, however, have to endure free atmosphere temperatures. On south exposed slopes, snow-melt starts in the first and second week of May. Between 2300 and $2500 \mathrm{~m}$ a.s.l. the duration of the growing season (until September) is normally $100-120$ days.

In the summers of 2001 and 2002 - climatically normal years - the monthly means of boundary layer temperatures (July and August) were about $9-11^{\circ} \mathrm{C}$; in 2003 - with an exceptionally long, warm and dry summer - mean temperatures were $11.7^{\circ} \mathrm{C}$ in July and $13.0^{\circ} \mathrm{C}$ in August [21]. The daily minimum temperatures during the summer were 

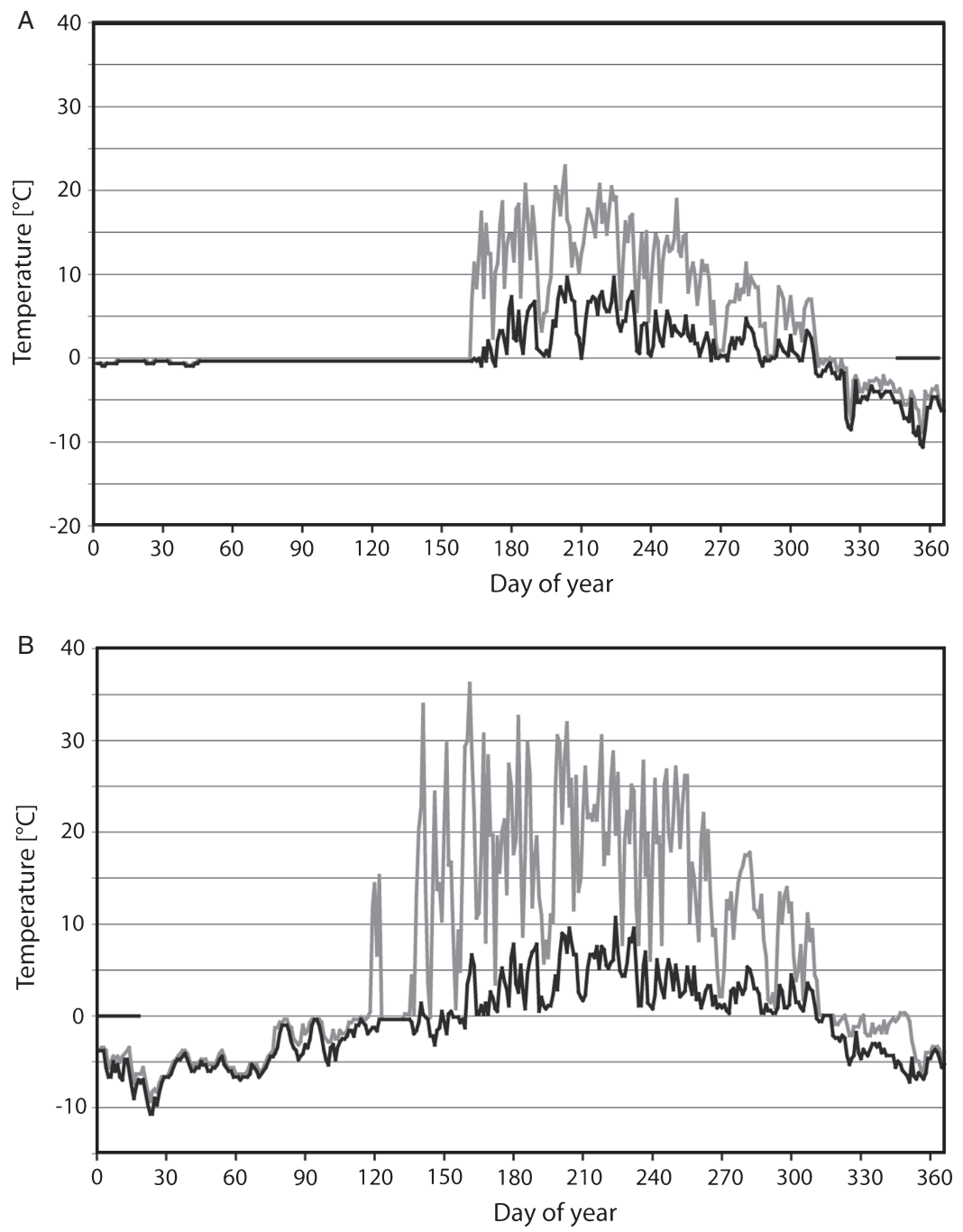

Fig. 5. Annual course of plant temperatures on a Northern Calcareous Mountain range (Hafelekar; $11^{\circ} 23^{\prime} 11^{\prime \prime} \mathrm{E}-47^{\circ} 18^{\prime} 46^{\prime \prime} \mathrm{N}$ ) in the climatically normal year of 2004; (A) a snow-rich northern site (2324 m a.s.1.); (B) a windy western ridge (2314 $\mathrm{m}$ a.s.1.). Upper line: daily maximum, lower line: daily minimum. Temperatures were recorded using small data loggers with a NTC-pearl sensor; loggers were protected from direct radiation [29] 


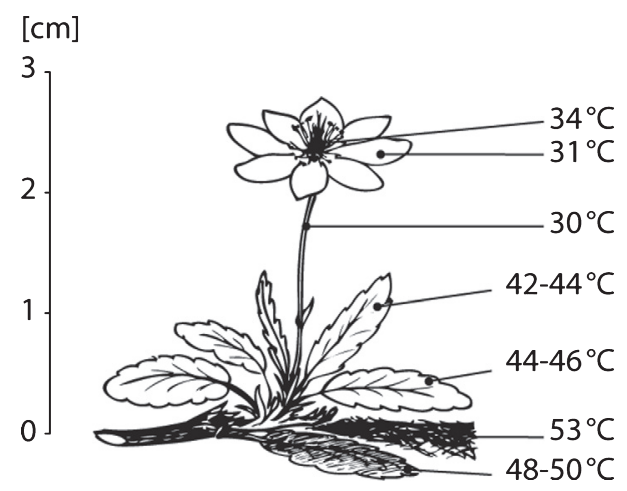

Fig. 6. Dryas octopetala in rocky habitats at $2300 \mathrm{~m}$ a.s.1. in midsummer with clear skies, dry soil and little wind. Living leaves were $42-46^{\circ} \mathrm{C}$, dead leaves $48-50{ }^{\circ} \mathrm{C}$, and litter and black humus on the soil surface were $53^{\circ} \mathrm{C}$. Measurements by W. LARCHER using thermocouples

$3-10^{\circ} \mathrm{C}$, daily maximum temperatures on a $\mathrm{N}$-slope about $20-25^{\circ} \mathrm{C}$ and on a W-slope $25-30^{\circ} \mathrm{C}$. In July and August temperatures between 5 and $10{ }^{\circ} \mathrm{C}$ were most common $(38 \%(\mathrm{~N})$ and $31 \%(\mathrm{~W})$ of total hours). The warmer temperature classes (above $10^{\circ} \mathrm{C}$ ) together added up to $37 \%(\mathrm{~N})$ and $39 \%(\mathrm{~W})$ of total hours.

Heat stress in high mountain regions is brought about by intensive incoming radiation, shelter from the wind and dry soil surface on $\mathrm{S}$ and SW facing slopes. During summer, prostrate plants of the alpine zone repeatedly reach maximum noon temperatures of $30-35^{\circ} \mathrm{C}$. On rocky sites plants can reach such high temperatures that some plant parts are prone to heat threat [3]. Small layering shrubs, e.g. Dryas octopetala, reached temperatures of more than $40{ }^{\circ} \mathrm{C}$ (Fig. 6). Even higher temperatures were found on Sempervivum rosettes; on midsummer days we repeatedly measured leaf temperatures of about $50{ }^{\circ} \mathrm{C}[26]$.

Cushion plants, especially on south exposed slopes, can also heat up considerably. On a clear day in midsummer Silene acaulis, Saxifraga oppositifolia and Carex firma were measured with an infrared pyrometer (PRT-10 L, Barnes, Stamford, USA) at sites $2300 \mathrm{~m}$ a.s.l. in the Northern Calcareous Alps [29]: maximum temperatures of $35^{\circ} \mathrm{C}$ were recorded in Silene and Saxifraga, and the dry cushions of Carex firma heated up to $46^{\circ} \mathrm{C}$. Even higher temperature maxima (above $40^{\circ} \mathrm{C}$ ) were measured in cushions of Silene acaulis by NEUNER et al. [34] at a subalpine site, resulting in maximum air to leaf temperature differences up to $22 \mathrm{~K}$. Dome-shaped cushions often show large differences in 
temperature between the sunny and the shady side. For Silene acaulis could be shown that the temperature gradient across the cushion reaches a maximum at 10 a.m. $(9 \mathrm{~K})$ and at 4 p.m. $(12 \mathrm{~K})$ and is smaller during the midday hours, when the angle of incidence of the solar radiation is higher [19].

\section{Temperatures in Pioneer Plants in the Glacier Region}

In the Central Alps, the microclimatic temperatures show marked differences between the subnival ecotone ("transition from the upper alpine to the nival zone"; [33]) and the nival zone. Temperatures were measured in the subnival ecotone in the glacier foreland of the Schaufelferner (2880 $\mathrm{m}$ a.s.l.; Stubai Alps) at a windy and rocky plateau with scattered vegetation and little snow cover in winter (Fig. 7A). Cushion species and isolated rosette plants were most commonly found in this scant patchy vegetation. Microclimatic temperatures in the nival zone were recorded on Mt Brunnenkogel (3440 $\mathrm{m}$ a.s.1.) in the Ötztal Alps. This mountain rises like a nunatak from the glacier area and is fully glaciated on the northern side. Small temperature loggers were placed on the soil surface between Ranunculus glacialis individuals (Fig. 7B).

During winter below the snow, temperatures were between -5 and $-10^{\circ} \mathrm{C}$ at both sites. However, during periods with a sparse snow cover plants experienced temperatures of down to ca. $-25^{\circ} \mathrm{C}$. At both localities, the snow melted between the end of June and the beginning of July in 2004. In autumn snow cover was complete at the beginning of September on Mt Brunnenkogel or at the end of September in the glacier foreland of the Schaufelferner. Thus, the duration of the snowfree period was 93 days at the subnival sites and 74 days on the summit of Mt Brunnenkogel.

During the growing season frosty temperatures were regularly measured in the sparse vegetation and at the soil surface. In midsummer (July and August) temperature minima between -2 and $-3{ }^{\circ} \mathrm{C}$ were recorded on about 20 days in the subnival ecotone and temperature minima down to $-5^{\circ} \mathrm{C}$ were recorded on about 50 days on the nival summit. Abrupt changes in weather patterns are characteristic of high mountain climate. After a cold wave, plants at these altitudes can be suddenly snowed in for several days (Fig. 8).

On the other hand, due to high irradiation, high boundary layer temperatures can also occur in the glacier region on clear days. From July until mid-August temperature maxima of about $25^{\circ} \mathrm{C}$ were 

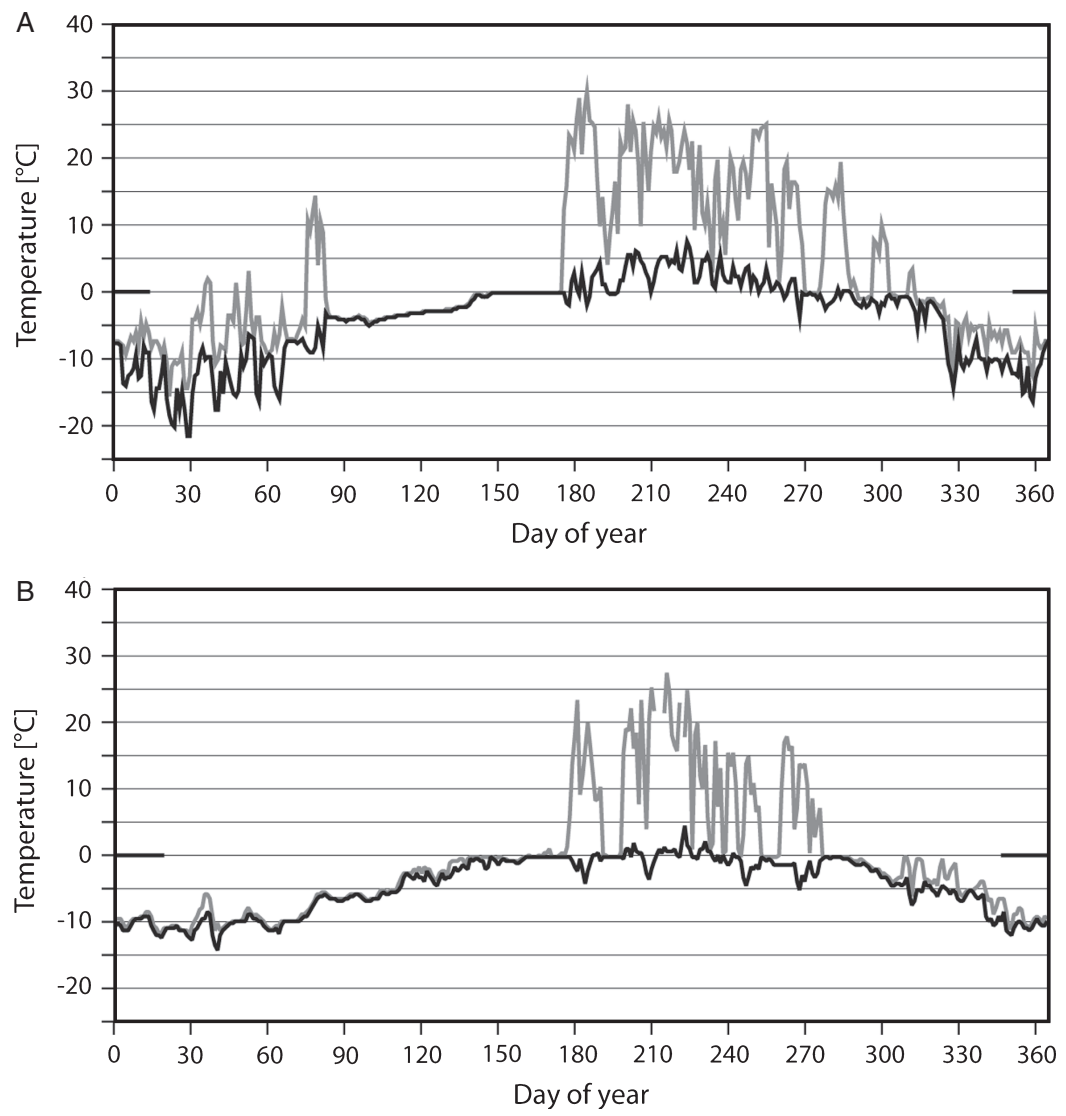

Fig. 7. (A) Annual course of boundary layer temperatures at a subnival site in the glacier foreland of the Schaufelferner in the Stubai Alps (2880 m a.s.1.; $11^{\circ} 06^{\prime} 56^{\prime \prime} \mathrm{E}-$ $46^{\circ} 59^{\prime} 14^{\prime \prime} \mathrm{N}$ ) in the climatically normal year of 2004 . A small temperature logger ("StowAway Tidbit") was installed in a cushion of Saxifraga bryoides. Upper line: daily maximum, lower line: daily minimum [29]. (B) Annual course of boundary layer temperatures at the nival site on Mt Brunnenkogel in the Ötztal Alps (3440 m a.s.l.; $10^{\circ} 51^{\prime} 42^{\prime \prime} \mathrm{E}-46^{\circ} 54^{\prime} 46^{\prime \prime} \mathrm{N}$ ) during the year 2004 . The temperature logger was placed in the shade of $R$. glacialis leaves. Upper line: daily maximum, lower line: daily minimum [28]

recorded at both sites. Overall boundary layer mean temperatures during the growing season were $8.2^{\circ} \mathrm{C}$ at $2880 \mathrm{~m}$ a.s.l. and $3.6^{\circ} \mathrm{C}$ at $3440 \mathrm{~m}$ a.s.1.

The difference between the subnival ecotone and nival zone is most clearly seen when comparing the frequency distribution of the number of hourly temperatures. During the snow-free period 33\% of hours 


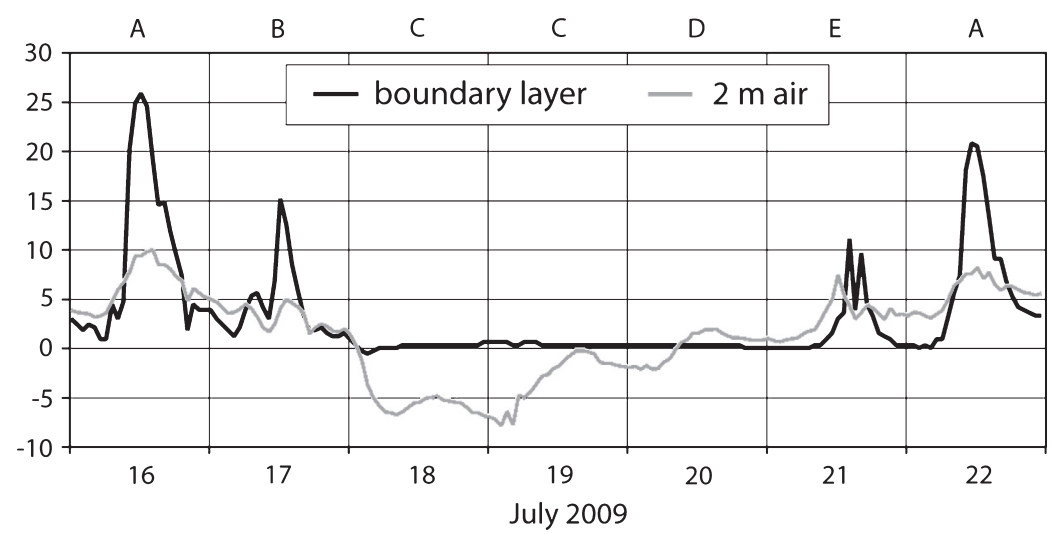

Fig. 8. Diurnal course of boundary layer temperatures and air temperatures at $2 \mathrm{~m}$ height on Mt Brunnenkogel (3440 m a.s.1.) during a cold wave in summer. (A) Clear skies at noon bring about overheating on the soil surface; clear nights can induce low temperatures in the morning due to re-radiation. (B) Beginning of cold front; (C) cold wave and snow fall; (D) snow covered sites; (E) snow melt. Temperatures were recorded by data loggers placed on the soil surface; air temperatures of the free atmosphere were provided by the Regional Centre for Meteorology (zamg.ac.at)

were between 0 and $5{ }^{\circ} \mathrm{C}$ (Schaufelferner) in contrast to $43 \%$ on $\mathrm{Mt}$ Brunnenkogel. Furthermore, on Mt Brunnenkogel, $31 \%$ of all hours showed temperatures of less than $0^{\circ} \mathrm{C}$. At $2880 \mathrm{~m}$ a.s.l. almost half of the night hours are between 0 and $+5^{\circ} \mathrm{C}$ whereas the temperatures of the daylight hours are more evenly distributed with about $20-25 \%$ of the hours in all temperature ranges between 0 and $20^{\circ} \mathrm{C}$. Subzero temperatures (absolute minimum -4 to $-4.5^{\circ} \mathrm{C}$ ) were measured in $6 \%$ of all hours at the subnival site and in $31 \%$ of all hours on the nival summit site. That means that in contrast to the subnival ecotone, boundary layer temperatures on summits in the nival zone frequently show subzero temperatures.

\section{Temperatures in the Phytosphere and Free Atmosphere Across the Altitude Zones}

Plant temperatures across the alpine and the nival zone in the Alps differ from free air temperatures provided by the weather services (Table 6). The vegetation cover under full solar radiation heats up so that the elevational gradient of the canopy temperatures is lower than that of the air temperatures. In dense canopies of Rhododendro-Vaccinietum communities the mean temperatures during the climatically potential 


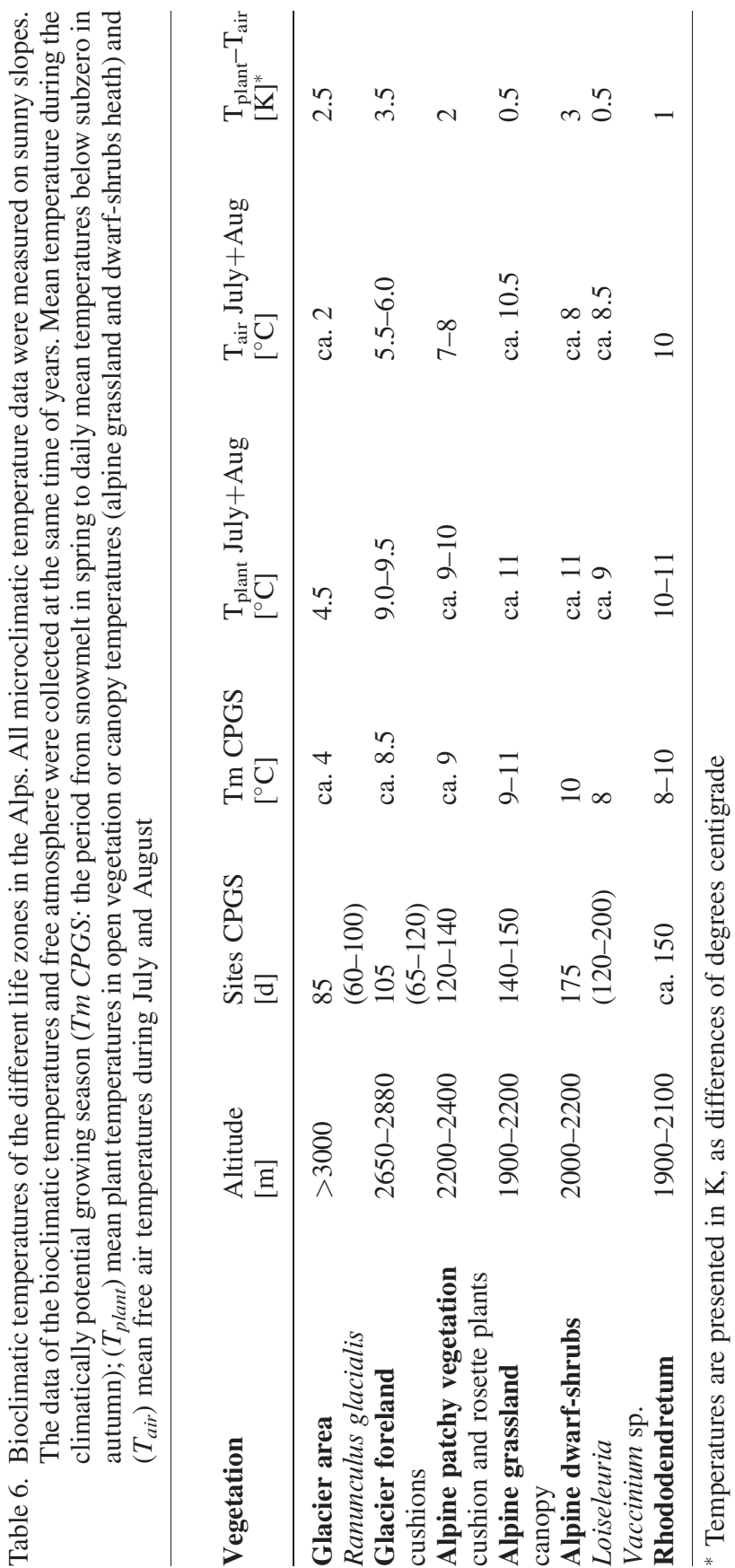


growing season (i.e. the period from snowmelt in spring to daily mean temperatures below subzero in autumn; [39]) were $8-10^{\circ} \mathrm{C}$; in the prostrate growing dwarf shrub communities (Loiseleuria heath) and in the sunny alpine grasslands they were between 9 and $11^{\circ} \mathrm{C}$; during the summer (July and August) canopy temperatures of about $11^{\circ} \mathrm{C}$ were measured. Beyond 2200-2300 m a.s.l. the mean plant temperatures did not pass the threshold of $9-10^{\circ} \mathrm{C}$ at any time during the growing season. In the upper alpine life zone and in the glacier foreland individual plants e.g. cushion and rosette plants and short graminoids had mean temperatures of $8-9^{\circ} \mathrm{C}$. At the nival microsites near the glacier mean temperatures were only $4.5^{\circ} \mathrm{C}$ during the active period of the plants. In the present study the adiabatic lapse rate of plant temperatures was $0.23^{\circ} \mathrm{C}$ per $100 \mathrm{~m}$ (2000-2880 m a.s.l.) for July and August.

Mean differences between plant temperatures and the free air temperatures amounted to $0.5-1 \mathrm{~K}$ in Vaccinietum communities mainly composed of erect plant forms. Mean temperature difference was $3 \mathrm{~K}$ in prostrate mats of the Loiseleuria heath, both for the canopy (see Table 5) and for shoot meristems 3-5 K [16]. Temperature difference was $2 \mathrm{~K}$ in rosette plants and $3 \mathrm{~K}$ in cushion plants.

\section{Conclusions}

Diversity in plants is reflected in the diversity of bioclimatic temperatures. The different plants architectures have an important influence on the different temperatures [18]. Measurements in different habitats at different elevations have shown that, under high irradiation, prostrate plants are thermally favoured and can accumulate more heat than erect forms. Thus, prostrate growth forms lessen the impact of the rough high mountain climate and allow alpine plants to successfully survive and reproduce. Most high mountain plants show a broad temperature amplitude for metabolism, growth and stress resistance [17]. Those plant species that stay in their habitat and show broad acclimatisation amplitudes or physiologically contrasting ecotypes [8-10] survive successfully. Under climate change conditions less acclimatised species have to migrate to adequate small-scale microsites $[12,15,45]$.

\section{Acknowledgements}

Many thanks to the Central Institute for Meteorology and Geodynamics, Regional Center for Tirol and Vorarlberg (Head Dr. KARL GABL), the Federal Office and Research Centre for Forests (data provided by G. WIESER; Innsbruck), the Institute of Ecology and the Institute of Botany, University Innsbruck (ULRIKE TAPPEINER, 
Michael bahn, Christian NeWeSEly; ERICH TASSER, and URSUla ladinig) for providing data. Thanks to "pdl, Dr. Eugen Preuss" Innsbruck, for image processing.

\section{References}

[1] AulitZKY, H. (1953) Forstmeteorologische Untersuchungen an der Wald- und Baumgrenze in den Zentralalpen. Archiv für Meteorologie, Geophysik und Bioklima B4: 294-310

[2] AULITZKY, H. (1968) Die Lufttemperaturverhältnisse einer zentralalpinen Hanglage. Archiv für Meteorologie, Geophysik und Bioklima B16: 18-69

[3] BuChneR, O., Neuner, G. (2003) Variability of heat tolerance in alpine plant species measured at different altitudes. Arctic Antarctic Alpine Research 35: $411-420$

[4] Cernusca, A. (1976) Bestandes-Struktur, Bioklima und Energiehaushalt von alpinen Zwergstrauchbeständen. Oecologia Plantarum 11: 71-102

[5] Cernusca, A. (1977) Bestandesstruktur, Mikroklima, Bestandesklima und Energiehaushalt von Pflanzenbeständen des alpinen Grasheidegürtels in den Hohen Tauern. In: CERnusCA, A. (ed.) Alpine Grasheide Hohe Tauern. Veröffentlichung des österreichischen MaB-Programms 1. pp. 25-45. Verlag Wagner, Innsbruck

[6] Cernusca, A. (1989) Struktur und Funktion von Graslandökosystemen im Nationalpark Hohe Tauern. Veröffentlichung des österreichischen MaB-Programms 13. Verlag Wagner, Innsbruck

[7] Cernusca A., Seeber, M. C. (1989) Phytomasse, Bestandesstruktur und Mikroklima von Grasland-Ökosystemen zwischen 1612 und $2300 \mathrm{~m}$ in den Alpen. In: CERNUSCA, A. (ed.) Struktur und Funktion von Graslandökosystemen im Nationalpark Hohe Tauern. Veröffentlichung des österreichischen MaBProgramms 13. pp. 419-461. Verlag Wagner, Innsbruck

[8] Crawford, R. M. M., Aвbott R. J. (1994) Pre-adaptation of arctic plants to climate change. Botanica Acta 107: 271-278

[9] Crawford, R. M. M., Chapman, H. M., AbBotT, R. J., Balfour, J. (1993) Potential impact of climatic warming on Arctic vegetation. Flora 188: 367-381

[10] DiEMER, M. (2002) Population stasis in a high-elevation herbaceous plant under moderate climate warming. Basic and Applied Ecology 3: 77-83

[11] FranZ, H. (1979) Ökologie der Hochgebirge. Ulmer, Stuttgart

[12] Gottfried, M., Pauli H., Reiter, K., Grabherr, G. (1999) A fine-scale predictive model for changes in species distribution patterns of high mountain plants induced by climate warming. Diversity and Distribution 5: 241-251

[13] Grabherr, G., Mucina, L. (1993) Die Pflanzengesellschaften Österreichs. II. Natürliche waldfreie Vegetation. Gustav Fischer Verlag, Jena

[14] Grabherr, G., Nagy, L., Thomson, D. B. A. (2003) An outline of Europe's alpine areas. In: NAGY, L., GrABHERR, G., KÖRnER, CH., ThOMSON, D. B. A. (eds.) Alpine biodiversity in Europa, pp. 3-12. Springer, Berlin Heidelberg New York

[15] Grabherr, G., GotTfried, M., Gruber, A., Pauli, H. (1995) Patterns and current changes in alpine plant diversity. In: CHAPIN, F. S., KÖRNER, CH. (eds.) Arctic and alpine biodiversity: patterns, causes and ecosystem consequences, pp. 167-181. Springer, Berlin Heidelberg New York 
[16] Grace, J., Allen, S., Wilson, C. (1989) Climate and meristem temperatures of plant communities near the tree-line. Oecologia 79: 198-204

[17] KöRNER, CH. (2003) Alpine plant life, 2nd edn. Springer, Berlin Heidelberg New York

[18] KöRner, CH., Cochrane, P. M. (1983) Influence of plant physiognomy on leaf temperature on clear midsummer days in the Snowy Mountains, south-eastern Australia. Acta Oecologia 4: 117-124

[19] Körner, Ch., De Moraes, J. A. P. V. (1979) Water potential and diffusion resistance in alpine cushion plants on clear summer days. Oecologia Plantarum 14: $109-120$

[20] Kronfuss, H. (1972) Kleinklimatische Vergleichsmessungen an zwei subalpinen Standorten. Mitt. Forstl. Bundes-Versuchsanstalt Wien 96: 159-176

[21] LADINIG, U., WAGNER, J. (2005) Sexual reproduction of the high mountain plant Saxifraga moschata Wulfen at varying lengths of the growing season. Flora 200: $502-515$

[22] LAdinig, U., WagneR, J. (2009) Dynamics of flower development and vegetative shoot growth in the high mountain plant Saxifraga bryoides L. Flora 204: $63-73$

[23] LARCHER, W. (1977) Ergebnisse des IBP-Projektes "Zwergstrauchheide Patscherkofel". SB Österreichische Akademie der Wissenschaften, Math-nat. Klasse I, 186: 301-371

[24] LARCHER W. (1985) Winter stress in high mountains. In: TURNER, H., TRANQUILLINI, W. (eds.) Establishment and tending of subalpine forest: research and management. Eidg. Anstalt forstl. Versuchswesen Birmensdorf, Berichte 270: $11-19$

[25] LARCHER, W. (1996) Das Verpflanzungsexperiment als Forschungsansatz für phänologische Analysen: Reproduktive Entwicklung von Rotschwingelgras in $600 \mathrm{~m}$ und $1920 \mathrm{~m}$ Meereshöhe. Wetter und Leben 48: 125-140

[26] LARCHER, W., WAGNER, J. (1983) Ökologischer Zeigerwert und physiologische Konstitution von Sempervivum montanum. Verhandlungen Gesellschaft für Ökologie 11: 253-264.

[27] LARCHER, W., WAGNER, J. (2004) Lebensweise der Alpenrosen in ihrer Umwelt: 70 Jahre ökophysiologische Forschung in Innsbruck. Berichte der Naturwissenschaften-Medizin Verein Innsbruck 91: 251-291

[28] LARCHER, W., WAGNER, J. (2009) High mountain bioclimate: temperatures near the ground recorded from the timberline to the nival zone in the Central Alps. Contributions to Natural History Museum Bern 12: 857-874

[29] Larcher, W., Kainmüller, C., Wagner, J. (2010) Survival types of high mountain plants under extreme temperatures. Flora 205: 3-18

[30] LARL, I., WAGNER, J. (2006) Timing of reproductive and vegetative development in Saxifraga oppositifolia in an alpine and a subnival climate. Plant Biology 8: $155-166$

[31] LOWRY, W.P. (1967) Weather and life. An Introduction to Biometeorology. Academic Press, New York

[32] Moser, W., Brzoska, W., ZachHuber, K., LARCHER, W. (1977) Ergebnisse des IBP-Projekts "Hoher Nebelkogel 3184m". SB Österreichische Akademie der Wissenschaften, Math-nat. Klasse I, 186: 386-419

[33] NAGY, L., GrabHERR, G. (2009) The biology of alpine habitats. Oxford Univ Press, Oxford 
[34] Neuner, G., Buchner, O., Braun, V. (2000) Short-term changes in heat tolerance in the alpine cushion plant Silene acaulis ssp. excapa (All.) J. Braun at different altitudes. Plant Biology 2: 677-683

[35] Neuner, G., Buchner, O. (in press) Dynamic of tissue heat tolerance and thermotolerance of PS II in alpine plants. In: LÜTZ, C. (ed.) Plants in alpine regions: Cell physiology of adaptation and survival strategies. Springer, Wien

[36] PROCK, S. (1990) Symphänologie der Pflanzen eines kalkalpinen Rasens mit besonderer Berücksichtigung der Wachstumsdynamik und Reservestoffspeicherung. Berichte der Naturwissenschaften-Medizin Verein Innsbruck 77: $31-56$

[37] SCHERrer, D., Schmid, S., KÖRnER CH. (2011) Elevational species shifts in a warmer climate are overestimated when based on weather station data. Int $\mathrm{J}$ Biometeorology, DOI: 10.1007/s00484-010-0364-7

[38] SiEgWolf, R. (1987) $\mathrm{CO}_{2}$-Gaswechsel von Rhododendron ferrugineum L. im Jahresgang an der alpinen Waldgrenze. Dissertation Innsbruck

[39] SvobodA, J. (1977) Ecology and primary production of raised beach communities, Truelove Lowland. In: BLISS, L. C. (ed.) Truelove Lowland, Devon Island, Canada: A high arctic ecosystem, pp. 185-216. University Alberta Press, Edmonton

[40] Tasser, E., Tappeiner, U., Cernusca, A. (2001) Südtirol Almen in Wandel. Ökologische Folgen von Landnutzungsänderungen. Europäische Akademie, Bozen

[41] Tranquillini, W., Turner, H. (1961) Untersuchungen über die Pflanzentemperaturen in der subalpinen Stufe mit besonderer Berücksichtigung der Nadeltemperaturen der Zirbe. Mitteilungen der Forstlichen Bundes-Versuchsanstalt Mariabrunn 59: 127-151

[42] TURNER, H. (1958) Über das Licht- und Strahlungsklima einer Hanglage der Ötztaler Alpen bei Obergurgl und seine Auswirkung auf das Mikroklima und auf die Vegetation. Archiv für Meteorologie, Geophysik und Bioklima B8: 273-325

[43] Wagner, J., Reichegger, B. (1997) Phenology and seed development of the alpine sedges Carex curvula and Carex firma in response to contrasting topoclimates. Alpine and Arctic Research 29: 291-299

[44] Wagner, J., Steinacher, G., LAdinig, U. (2010) Ranunculus glacialis L.: successful reproduction at the altitudinal limits of higher plant life. Protoplasma 243: $117-128$

[45] Walter, H., Walter, E. (1953) Das Gesetz der relativen Standortskonstanz: Das Wesen der Pflanzengesellschaften. Berichte deutsche botanische Gesellschaft 66: $228-236$

[46] Wieser, G. (2007) Climate at the upper timberline. In: WiESER, G., TAUSZ, M. (eds.) Trees at their upper limit. Treelife limitation at the alpine timberline, pp 19-36. Springer, Dordrecht

\section{Internet:}

Zentralanstalt für Meteorologie und Geodynamik: www.zamg.ac.at

Authors' address: em. Prof. Dr. Walter Larcher and A. Prof. Dr. Johanna Wagner, Institut für Botanik der Universität Innsbruck, Sternwartestrasse 15, A-6020 Innsbruck, Österreich. E-Mail: walter.larcher@uibk.ac.at; johanna.wagner@uibk.ac.at 